\title{
Another Word on Parents, Subsidiaries and Affiliates in Bankruptcy
}

\author{
Jonathan M. Landers $†$
}

To those of us who labor in the dark recesses of bankruptcy law, it is encouraging to see the obvious talents of Professor Richard Posner brought to bear on the recurrent problems of equitable subordination, veil piercing and consolidation. When the product is combined with a "general introduction to the economic analysis of problems in corporation law" and is presented in a tight twentyseven page bundle, it should be worthy of special attention. ${ }^{1}$ Alas, though Professor Posner's mastery of economics is readily apparent, the economic analysis which fuels his discussion has-at least insofar as the bankruptcy issues are concerned-quickly powered it off the track.

At the outset, a brief recapitulation of my prior discussion may be helpful. ${ }^{2} \mathrm{My}$ initial premise was that investors in a single corporate enterprise $\mathrm{e}^{3}$ seek to gain the largest possible return on their investments consonant with the risks they wish to take. As long as overall return is maximized, the investors have little reason to concern themselves with the profitability-or even viability-of individual corporate units. Creditors of a multi-corporate enterprise will thus face certain dangers not faced by creditors of a single corporation. These dangers include:

$\dagger$ Professor of Law, University of Illinois. During the academic year 1975-76, I was a Visiting Professor at the University of Chicago Law School, where the issues discussed here became somewhat of a cause celèbre. During that time, I benefited from numerous comments from the faculty. I specifically wish to acknowledge the many helpful criticisms of Professors Phil Neal, John Langbein and Richard Epstein in connection with this paper.

1 Posner, The Legal Rights of Creditors of Affiliated Corporations: An Economic Approach, 43 U. CHI. L. REv. 499 (1976) [hereinafter cited as Posner].

${ }^{2}$ Landers, A Unified Approach to Parent, Subsidiary and Affiliated Questions in Bankruptcy, 42 U. CHI. L. REv. 589 (1975) [hereinafter cited as Landers]. Two recent cases setting out the modus operandi of such an enterprise in somewhat greater detail than usual are In re Mobile Steel Co., 5 Collier Bankr. CaSEs 17 (S.D. Ala. 1975) (Bankruptcy Judge); In re D.H. Overmyer Co., 2 Bankr. Ct. Dec. 412 (S.D.N.Y. 1976) (Bankruptcy Judge).

"I defined an "enterprise" as "the combination of parent, subsidiary and affiliated corporations." Landers at 590. 
(1) the lesser importance of adequate initial capitalization;

(2) the making of corporate decisions with a view to overall return on investment rather than the profitability or viability of a particular corporate unit; and the concomitant danger that any given entity will not be operated as a separate profit-making firm with a realistic potential for profitability;

(3) the danger of commingling assets and properties, or the artificial allocation of properties among constituent companies;

(4) the use of available funds where they will produce the greatest possible return, and not in terms of the business needs of one or the other of the units;

(5) the likelihood that creditors may be misled regarding the ownership of assets available to satisfy debts or regarding which individual firm will respond for the debt;

(6) the possibility that one firm will become overly dependent on the others for funds, business activity, or both;

(7) the selective use of the resources of one constituent company to help another to the prejudice of creditors of both firms, and the inability to reallocate such intangible factors as the time spent by key personnel on one or another constitutent company or lost opportunities resulting from an overcommitment of resources to a struggling company; and

(8) the effect of related companies on each other's reputation and operation, and the possibility that the affairs of one had direct or indirect, but indeterminable, impact on the affairs of the other. ${ }^{4}$

These considerations led me to suggest that, with some significant exceptions,

(1) the parent's debt in its affiliate should always be subordinated;

(2) creditors of the subsidiary should be able to pierce the veil of the parent; and

(3) if both parent and subsidiary are bankrupt, the estates should be consolidated and all creditors should share equally.

Professor Posner does not deny that the dangers outlined above exist. Nor could he, since one or more figure in every pertinent case he has cited. ${ }^{5}$ Professor Posner's response is threefold. First, credi-

- This is not to say that creditors are never benefited by the multi-corporate nature of their debtor. In conglomerate merger cases, for example, the government may object to the acquisition of one concern by another on the ground that it makes the resulting concern too strong. See, e.g., Turner, Conglomerate Mergers and Section 7 of the Clayton Act, 78 Harv. L. REv. 1313, 1322-93 (1965); note 12 infra.

5 Posner at 520 n. $35,522 \mathrm{nn} .40 \& 41$. In addition to the examples in my original 
tors are already compensated in the form of interest rates or higher prices for the risks they take. Second, an enterprise approach would raise the cost of credit by requiring creditors of one unit in a corporate enterprise to investigate the credit-worthiness of all other units. Third, the lack of concern for the profitability of enterprise units is inefficient; in a well-managed concern, separate corporate units would be treated as independent "profit centers."

II

\section{A. Risk and Interest Rates}

Professor Posner's basic thesis is that all incremental changes in risk result in differentials in interest rates or prices. ${ }^{6}$ The effect of adopting an enterprise approach to bankruptcy problems would, in his view, simply be to alter interest rates or prices because of the altered risks. But this would be inefficient because of the additional costs creditors would incur in investigating the credit-worthiness of related firms. In short, present interest rates accurately reflect single-unit risk in the most efficient manner.

The major premise of Professor Posner's theory is that most creditors advance credit in situations where different interest rates or prices are charged for incremental levels of risk. Initially, Professor Posner recognizes that this theory does not work in two major cases. First, since it is based on a creditor's obtaining an accurate picture of the risk, it cannot work where the costs of acquiring adequate information are disproportionate to the amount of the transaction. ${ }^{7}$ Second, it does not work at all in the case of involuntary creditors. ${ }^{8}$ Professor Posner places the tort creditor in this category but conveniently ignores a class of creditors that has even more bankruptcy significance-the tax collectors at all levels of government. There are, admittedly, no accurate figures on the proportion of bankruptcy claims made by creditors within the Posner exceptions, but there is reason to think that the number is substantial. ${ }^{\circ}$

discussion, see, e.g., In re Continental Vending Mach. Corp., 517 F.2d 997 (2d Cir. 1975), cert. denied, __ S.Ct. __ (1976); In re Equity Funding Corp., 396 F. Supp. 1266, 1270-71 (C.D. Cal. 1975); In re D.H. Overmyer Co., 2 Bankr. Ct. Dec. 412 (S.D.N.Y, 1976) (Bankruptcy Judge). There are allegations of similar conduct by the mammoth Penn Central. See DouglasHamilton, Creditor Liabilities Resulting from Improper Interference with the Management of a Financially Troubled Debtor, 31 Bus. LAw. 343, 350 (1975).

- Posner at 501-05, 507-09.

7 Id. at 506; see 507-08.

"Id. at 506, 507.

- It is difficult to examine many bankruptcy questions, including this one, because of 
Furthermore, many creditors simply do not individualize their transactions to the degree assumed by Professor Posner. A substantial portion of creditors who theoretically could afford to investigate the credit-worthiness of their customers in fact fail to do so; even those who do investigate often do not alter rates or prices to reflect. differential levels of risk. For example, it is common for suppliers of goods and services to have standardized prices for goods and credit terms. The widespread quotation of prices such as " $2 \% / 10$ days, cash/30 days" reflects a uniform pricing system that saves transaction costs by reducing the need for individual decision making and supervision. And even trade creditors who do make some initial investigation tend to be favorably influenced by a history of regular payments. This relatively economical way of estimating risk will be dangerous where the regular payments by one corporate unit have been made possible by the advances of its corporate relations. I would apply a per se rule of piercing in this situation, with the previously set forth qualifications, to protect creditors as fully as possible. Professor Posner's misrepresentation test, on the other hand, would catch only some of these cases. And it is, I would argue, cases in which only limited investigation is possible with which we must be primarily concerned. There is absolutely no evidence that most creditors who appear in the bankruptcy court for their meager share of the bankrupt's assets have conducted the kind of nitpicking investigation implicit in Professor Posner's hypothesis. Consequently, it is doubtful that the enterprise theory would greatly increase investigation costs.

The process of risk estimation itself, which lies at the heart of Professor Posner's theory, is much less certain than he supposes. For

an almost total absence of reliable data. The Brookings Study did break down claims by class for business bankruptcies and Chapter XI proceedings. Claims for taxes, wages and services comprised roughly 10 percent of the total, merchandise suppliers almost 30 percent, and rent 15 percent in straight bankruptcy cases. Many of these would fall within one of the excepted classes. In addition, 13 percent of the straight bankruptcy claims and 28 percent of the Chapter XI claims could not be categorized, but some of these also might fall within the exceptions. D. Stanley \& M. Girth, Bankruptcy: Problem, Process, Reform 253 (1971). See also id. at 130-31 (discussing tax claims). In attempting to categorize claims, the authors noted: "Often it was impossible to distinguish between the personal and the business obligations of sole proprietors and partners ...."Id. at 253. The Administrative Office has published figures on bankruptcy cases, but they are not separated for business cases. Such statistics were published for fiscal year 1969, but figures for fiscal year 1974 were presented to Congress in connection with proposed bankruptcy legislation. ADMIN. OFFICE OF THE U.S. Courts, Tables of Bankruptcy Statistics (1969); Hearings on H.R. 31 and H.R. 32 Before the Subcomm. on Civil and Constitutional Rights of the House Comm. on the Judiciary, 94th Cong., 1st Sess., Ser. 27, pt. 1, at 37-38 (1975). 
example, Professor Posner acknowledges that it is impossible to compensate creditors adequately for unpredictable risk; he includes in this category the risk that the debtor will obtain other unsubordinated loans. ${ }^{10}$ But this is hardly an unusual risk since most debtors retain full power to incur future credit obligations, and most creditors, including virtually all trade creditors, do not insist on any protection against this risk. Even when creditors do insist on such protection-usually in transactions involving large extensions of credit-these limitations customarily take the form of requiring minimum asset-to-liability ratios or restricting further large debts. To the extent that trade creditors do investigate, they generally rely on the debtor's history of payment and its tangible assets. Thus a major component of risk is inestimable. ${ }^{11}$ Furthermore, since Professor Posner acknowledges that veil piercing, consolidation, and subordination may sometimes be in order, his own approach requires that an additional risk be taken into account. Where veil piercing or subordination is ordered, creditors of one corporate unit will be adversely affected by the debts of the other unit. Professor Posner's logic would imply that the creditor of one unit must therefore estimate the uncertain prospects that creditors of another unit may reach the assets of its particular debtor. Certainly, this will not help creditors to appraise credit risks intelligently.

Professor Posner's criticism of the enterprise approach seriously overstates its potential impact on the credit process. Professor Posner implies that adopting the enterprise approach would operate to convert non-bankrupt corporate units into bankrupts. In fact, this will only be true in the rare case in which subordination or veil piercing turns a parent or affiliate from solvency to insolvency. Ordinarily, however, the major impact of adopting the enterprise approach would be to increase the realization of creditors of a bankrupt subsidiary, and to do so at the expense of stockholders of the non-bankrupt parent. In my view, the enterprise nature of related corporate units justifies such a result. Moreover, in the ordinary case in which the issue for creditors is not the risk of bankruptcy,

10 Posner at 504-05.

1" Creditors who are not satisfied with this situation insist on adequate security. Creditors may also protect themselves by contract or cross-guarantees of affiliates. Such creditors admittedly do not need the enterprise theory. See Chemical Bank New York Trust Co. v. Kheel, 369 F.2d 845 (2d Cir. 1966) (large creditor opposing consolidation; creditor's mortgage was previously held invalid); cf. In re Cushman Bakery, 526 F.2d 23 (1st Cir. 1975) (creditor took mortgate of assets of related companies). Such guarantees are not uncommon. See Landers at $635 \&$ n. 148. 
but the risk of different realizations in bankruptcy, creditors are unlikely to devote additional resources to investigating the enterprise or to tie their interest rates to this kind of risk. The differential risk introduced by the enterprise approach will simply not be worth investigating in light of high information costs and the generally low yields to creditors in bankruptcy. Thus, the enterprise approach can be expected to have only a minimal impact upon interest rate decisions of creditors.

\section{B. Efficiency and the Profitability of Enterprise Units}

Professor Posner also argues that a multi-unit corporate enterprise ought to operate the individual units not as components of a single enterprise but rather as individual "profit centers." If this were the case, creditors of one of the component corporations would not be exposed to the enterprise dangers I mentioned earlier. Now, the term "profit center" certainly has a lean and efficient look. ${ }^{12}$ However, inherent in the "profit center" approach is an inaccurate model and an unsupported factual assertion.

Professor Posner builds his model of corporate activity on seductive examples from such diverse fields as steel and cornflakes, or mining and broadcasting. ${ }^{13}$ But this is a distortion. Such conglomerates do not present the typical case that appears either in the corporate world or the bankruptcy court. Most multi-unit corporate enterprises involve interrelated businesses; indeed, Professor Posner has not found a single bankruptcy case that did not. ${ }^{14}$ The reason is obvious: separate corporate units are usually formed either to further a business need of the investor or to capitalize on the skills developed in one line of activity. Professor Posner's steel company that has capital available for investment is more likely to invest in a metals or manufacturing activity than in a cornflakes company for the very reason he states - the information costs are much less and

12 Professor Posner borrows the term from affidavits of ITT officials trying to support a merger against antitrust attack. See United States v. International Tel. \& Tel. Corp., 306 F. Supp. 766, 790 (D. Conn. 1969). Apparently, however, ITT officials did not take the profit center approach quite as seriously as Professor Posner. Landers at 651 \& n.190. Moreover a consent decree settling the Government's antitrust case against ITT specifically forbade many of the practices I have identified as enterprise dangers. United States v. International Tel. \& Tel. Corp., 349 F. Supp. 22, 34-35 n.16 (D. Conn.), aff'd, 410 U.S. 919 (1972).

13 Posner at 512-13, 516-17.

14 Virtually all the cases I have cited conform to this model. There are, to be sure, some exceptions. See, e.g., In re Beck Indus., Inc., 479 F.2d 410 (2d Cir.), cert. denied, 414 U.S. 858 (1973); cf. In re Adolf Gobel, Inc., 80 F.2d 849 (2d Cir. 1936). 
the likelihood of an accurate prediction of value much greater..$^{15}$ In fact, virtually all bankruptcy cases involve corporations in related fields, and almost all of these involve closely held corporations. Even assuming that some of Professor Posner's assertions are valid for large and highly diversified conglomerates, he is therefore toying with a false model of the problem.

Professor Posner's "profit center" theory is also factually incorrect. Many corporate managers do not in fact behave according to the Posnerian ideal-they do not strive toward maximum profitability of each individual corporate unit. Both of us have cited numerous instances, including some involving large and presumably wellmanaged companies, ${ }^{16}$ that amply illustrate this fact. Let us take another example. It was recently reported that the sales finance subsidiaries of some automobile makers had extended the maturity of automobile paper from the conventionalthirty-six months to periods of forty-two, forty-eight or even sixty months. ${ }^{17}$ These extensions may reduce the profitability of the sales finance subsidiaries because the increased risk will not be offset by sufficiently higher interest rates. The purpose of the extensions was not to increase profitability of the subsidiaries, however, but to sell more of the parents' cars. Unlike Professor Posner, I am unwilling to call the managers of the automobile enterprises inefficient or irrational because they chose not to operate their sales finance subsidiaries as independent "profit centers." 18

\section{Veil Piercing, Subordination, and Consolidation}

In sum, Professor Posner's theory that incremental risks are accurately reflected in interest rates is seriously flawed; many creditors do not undertake thorough credit investigation, and even those who do attempt to estimate risks are likely to be unable to do so accurately. Professor Posner's "profit center" model is not an accurate reflection of the way business is conducted. The enterprise theory reflects a more honest picture. Even Professor Posner begrudgingly admits that the enterprise theory may be more accurate

${ }^{15}$ See Turner, supra note 4 , at 1315.

16 See, e.g., Comstock v. Group of Institutional Investors, 335 U.S. 211 (1948); Taylor v. Standard Gas \& Elec. Co., 306 U.S. 307 (1939); In re Continental Vending Mach. Corp., 517 F.2d 997 (2d Cir. 1975), cert. denied, S.Ct. (1976); In re Unishops, Inc., 494 F.2d 689 (2d Cir. 1974); Gannett Co. v. Larry, 221 F.2d 269 (2d Cir. 1955); In re Equity Funding Corp., 396 F. Supp. 1266 (C.D. Cal. 1975).

'Wall St. J., Oct. 2, 1975, at 1, col. 5 (eastern ed.).

ix See Posner at 513-15. 
in the case of closely held corporations-which, of course, represent the overwhelming majority of bankrupts. ${ }^{19}$ With this background, the three proposals put forward in my paper may be considered.

1. Veil Piercing. Professor Posner admits that his interest rate theory applies neither to involuntary creditors nor to those voluntary creditors for whom information costs are too high. But he seems initially uncertain whether these creditors should be permitted to pierce the corporate veil. ${ }^{20}$ Despite his reluctance, however, there is no choice. If courts ordinarily refrain from veil piercing because creditors have already exacted compensation for their inability to pierce by demanding higher interest rates or prices, it should follow that creditors who are not compensated in this way should be able to pierce. This position represents a substantial shift from the present law-although Professor Posner does not acknowledge that fact-and I fully agree with it. I do not agree, however, with Professor Posner's prediction of the number of creditors who will qualify: my own estimate is that if all creditors who found it difficult to obtain accurate risk information were permitted to pierce, Professor Posner's exception would probably swallow the conventional non-piercing rule.

Professor Posner would recognize a second exception for creditors who were misled. ${ }^{21}$ Despite intimations to the contrary, it seems unlikely that Professor Posner would require the deception to meet the standards of common law fraud. He would presumably want to protect the creditor who is fooled by the regular payment of bills from the funds of another affiliate, or the creditor who relies on a similarity of names. While these creditors have been misled, it is questionable whether there was the kind of intentional misrepresentation required in common law fraud. Of course, it is difficult to know precisely what would fall within the pure misrepresentation standard since, although the veil piercing issue has been around for the better part of a century, Professor Posner has not found a single case in which the misrepresentation approach was applied. ${ }^{22}$

19 Posner at 511, 515. Indeed, Professor Posner recognizes the similar problem of one-man corporations. Id. at 511.

${ }^{20}$ Posner at 519-20, 521-22; see id. at 506, 523.

${ }^{21}$ Professor Posner is unclear whether misrepresentation should be the exclusive basis for veil piercing, or whether piercing is also permitted if the traditional viability-procedural observance test is not met. See National Marine Serv., Inc. v. C.J. Thibodeaux \& Co., 501 F.2d 940, 942 (5th Cir. 1974); Landers at 620-26.

${ }^{22}$ Professor Posner does cite cases discussing the presence or absence of misrepresentation, and, as already noted, misrepresentation is a common factor in parent-subsidiary cases. Posner at 514 n.28. A good example of such a case and of the difficulties with the 
Professor Posner's proposal also runs afoul of some traditional bankruptcy principles. For example, the trustee ordinarily represents creditors in bankruptcy proceedings, whereas Posner's proposal would give rise to litigation in which individual creditors would have to represent their own interests and collect their own claims. In fact, Professor Posner contemplates not a bankruptcy doctrine at all, but essentially a state law claim to be prosecuted individually by creditors. ${ }^{23}$ To some extent, his proposal conflicts with the bankruptcy view that all creditors should be treated alike regardless of the source of the particular assets available to creditors in bankruptcy or the particular rights asserted by the trustee to bring those funds into bankruptcy. ${ }^{24}$ The latter principle reflects a desire to spread the costs of bankruptcy equally among creditors and to minimize the administrative costs of collecting and distributing the bankrupt's assets.

Professor Posner expresses a special and somewhat uncharacteristic fear of piercing in the close corporation area. Suppose, he says, that a person has all of his fortune in corporation $A$ and wants to invest some of it in corporation $B$. Were piercing allowed, this person could lose his entire fortune. The result would be similar to piercing the veil of a one-man corporation to reach the assets of the sole shareholder. ${ }^{25}$

But surely, Posner's case is overstated. If the veil of a one-man corporation were pierced, the effect would be to reach such assets as a home, car, furniture, or clothing. It is hardly likely, however, that even a person who had most of his financial assets in corporation $A$ would include his home or car among those assets. Indeed,

misrepresentation approach, is American Trading \& Prod. Corp. v. Fischbach \& Moore, Inc., 311 F. Supp. 412 (N.D. Ill. 1970).

The one case directly cited for the misrepresentation theory is Krivo Indus. Supply Co. v. National Distillers \& Chem. Co., 483 F.2d 1098 (5th Cir. 1973). Posner at 514 n.29. Unfortunately, Professor Posner has read that case too quickly. The issue was not the conventional one of veil piercing to reach a corporate stockholder, but, rather, involved the attempt of one creditor to recover its claim against another creditor that had become heavily involved in running the debtor's business. The questions are quite different. See In re Process-Manz Press, Inc., 236 F. Supp. 333, 348 (N.D. 1ll. 1964), rev'd on other grounds, 369 F.2d 513 (7th Cir. 1966), cert. denied, 386 U.S. 957 (1967); cf. In re Cushman Bakery, 526 F.2d 23, 31-32 (1st Cir. 1975); In re Simpson, 222 F. Supp. 904, 908-09 (M.D.N.C. 1963); Langan v. First Trust \& Deposit Co., 293 N.Y. 604, 59 N.E.2d 424 (1944).

${ }^{23}$ Cf. Landers at 607-16.

2s See Moore v. Bay, 284 U.S. 4 (1931); Bankruptcy Act 67d(6), 11 U.S.C. 107 (d)(6) (1970) (trustee can set aside conveyance fraudulent as to creditor with a provable claim); cf. Countryman, Improvident Credit Extension: A New Legal Concept Aborning? 27 ME. L. Rev. 1, 21-22 (1975).

25 Posner at $512-13,515,516$. 
in many states, such assets receive special protection through exemption laws. Even assuming that most of a person's assets are in corporation $A$, what are the policy choices? Professor Posner would put the loss on the creditors, with some possible exceptions for involuntary and high-information-cost creditors. I would put it on the investors (owners of the parent) in the first instance.

2. Subordination. My point was that debts of a parent should be subordinated not only because of the usual enterprise factors, but also because such debts are more inherently risk capital than debts of other creditors. Professor Posner does not really deny that this is the case, but simply suggests that the parent is sometimes the most efficient lender because of its lower information costs. ${ }^{26}$ This argument cannot be taken seriously. In fact, virtually all the cases involve loans or advances that an outside lender would not make at all or, at least, would not make on equally favorable terms. A better explanation is that the parent has an additional incentive to make the loan insofar as it seeks to preserve its investment in the subsidiary. Also, owners may be more optimistic than outsiders because their judgment is based on impaired vision or wishful thinking. One can make a strong argument-as does Professor Posner-that the outside lender is in a better position to make a realistic appraisal of the risk since he is free of emotional factors such as a reluctance to see a unit of the enterprise go under or a desire to preserve a shaky investment. ${ }^{27}$ Advances from the parent sometimes benefit existing creditors by infusing new resources and staving off bankruptcy. But such advances obviously harm subsequent creditors, who would otherwise never have become creditors, and often harm existing creditors, for whom a postponed bankruptcy may mean a lower realization.

Professor Posner's interest rate rationalization does not really address the subordination issue. Posner is concerned with interest rates as a reflection of the risk of default; if the subsidiary has become bankrupt, there has already been a default. Professor Posner has not demonstrated any significant correlation between interest rates and the prospects of realizations in bankruptcy, either under the present or the enterprise approaches; in view of the small dividends usually paid in bankruptcy, ${ }^{28}$ the information expense

${ }^{26}$ Posner at 518.

27 Posner at 501-02, 508-09.

28 The 1969 figures show that dividends were paid to unsecured creditors in 13.6 percent of all straight bankruptcy cases, and in these cases 7.8 percent of unsecured claims were paid. Tables of BankRUPTCY Statistics, supra note 8, at Tables F4a, F6. The 1974 figures were 11.2 
would simply be too high. Instead, Professor Posner is forced to retreat to his misrepresentation approach. As previously noted, however, use of this approach would require automatic subordination to all involuntary creditors and all creditors who could prove that their information costs were too high.

Professor Posner's test, by requiring voluntary creditors seeking subordination to show either that their information costs were too high or that they were misled, would require individualized proof by each creditor of facts unique to its transaction. While Professor Posner does suggest treating groups of creditors as a class, misrepresentation is not the kind of claim that lends itself readily to class adjudication. Indeed, the pressures of class adjudication have been largely responsible for the elimination of the need to prove reliance in securities fraud class actions. ${ }^{29}$ Insofar as other creditors are concerned, the duty to investigate will presumably vary in part according to the amount of the transaction and the creditor's prior dealings with the bankrupt. Professor Posner proposes no effective mechanism for proving such matters. ${ }^{30}$

The notion that each creditor can establish his right to subordination only on an individual or class basis flies directly in the face of a consistent movement to simplify the claims procedure. The Bankruptcy Act specifically required the court to pass on claims, but the Bankruptcy Rules changed this procedure to provide that claims are automatically allowed..$^{31}$ In reorganization cases, credi-

percent of asset cases, and 4.1 percent of claims. Hearings on H.R. 31 and H.R. 32, supra note 8 , at $93-94$. These figures exaggerate payments somewhat since only proved claims may be allowed, and all creditors do not prove their claims. In Chapter XI cases, the plans provided for payment of 38 percent of unsecured claims. TABLES of BankRuptcy STATISTICS, supra, Table F11. However, the amount actually received by creditors was considerably less since such plans often fail.

The Brookings study reported that claims were paid to unsecured creditors in 44 percent of all business cases, but again, creditors received an average of 8 percent of the amounts proved and allowed. D. STANLEY \& M. GiRTH, supra note 8, at 130. In Chapter XI cases, creditors in one-payment plans received 19 percent of their claims; creditors in deferred payment plans received a median of 10 percent of their claims at confirmation, and promises of future payments of a median 25 percent of their claims. Id. at 139.

The message is clear: general creditors do not get much in bankruptcy. Even the above figures must be discounted by the costs of proving claims and the danger to the creditor that, by participating in the bankruptcy process, the creditor will be subject to greater vulnerability to an attack by the trustee on a previous transaction with the bankrupt. See Katchen v. Landy, 382 U.S. 323, 339 (1966).

29 See Landers, Of Legalized Theft: Consumer Class Actions and the SubstanceProcedure Dilemma, 47 S. CAL. L. Rev. 842, 865-66 (1974).

${ }^{30}$ Professor Posner is unclear whether subordination will still be permitted on traditional grounds. See Landers at 597-98.

"Bankruptcy Rule 306(b). 
tors do not even have to prove their claims, which are allowed in the amounts scheduled; creditors need only take action if they disagree with that amount. ${ }^{32}$ Such provisions stand as a practical recognition of the fact that creditors will generally incur no more than nominal expenses to collect the usually small dividend paid in bankruptcy. As a practical matter, Professor Posner's proposal would deter all but the largest creditors from seeking subordination because of disproportionate costs. And, ironically, it is these largest creditors who, because they were in the best position to investigate the facts, are least likely to warrant subordination.

3. Consolidation. Professor Posner is undoubtedly right that in cases of large creditors, the enterprise approach permitting consolidation will require investigation of other units. But I suspect that creditors in such cases already conduct such investigations. There is at least some evidence that creditors require collateral belonging to the nominal debtor's affiliates as well as crossguarantees, thus suggesting that creditors themselves frequently recognize the enterprise approach on their own. ${ }^{33}$ Moreover, in view of the small dividends usually paid in bankruptcy-with or without consolidation-it is unlikely that creditors will investigate very carefully the likelihood of different treatment in the event of consolidation. Finally, my approach would protect a creditor's proven reliance.

4. Administrative Costs of the Posner Proposal. Adoption of Professor Posner's proposal would result in an increase in the administrative cost of adjudicating these issues. By making veil piercing, subordination, or consolidation turn upon the proven intercorporate relationships as well as the perceptions of particular creditors, his proposal would increase the number of issues that must be adjudicated. At present, the trustee has responsibility under section $47 \mathrm{a}(8)$ for attacking the parent's claims and under section $70 \mathrm{a}$ or $70 \mathrm{c}$ to try to pierce the veil. Superimposed upon this is some power to effect these results at the insistence of individual creditors, although the interrelationships between creditors as well as the precise responsibilities of the trustee are unclear. Professor Posner's proposal, however, can only result in more issues, more lawyers, more briefs and more witnesses. Professor Posner has not justified this inevitable increase in administrative costs, which itself will ultimately raise the overall cost of credit.

${ }^{32}$ Bankruptcy Rule 10-401.

${ }^{33}$ See In re Cushman Bakery, 526 F.2d 23 (1st Cir. 1975); Landers at 635-36 \& nn.14449. 
Although the decision to subordinate and pierce the veil may, as Professor Posner recognizes, have some indirect effect on creditors of the parent, the most significant effect will be on the owners of the parent, whose claims will be disallowed and whose investment in the parent will be reduced by the need to pay creditors of the subsidiary. Put another way, the owners of the parent are the primary beneficiaries of the present system. Under the present tests for subordination and veil piercing as well as that proposed by Professor Posner, however, the creditor seeking subordination or the trustee seeking to pierce the veil has the burden of showing that the parent's owners have somehow abused their corporate office or responsibilities. But this is a particularly difficult burden to carry since the owners have the relevant data and the trustee and outside creditors generally do not.

Consequently, the present system effectively rewards owners who can hide from public view the enterprise nature of their business operations. In the analogous area of fraudulent conveyances, such a reality has been recognized by a variety of special rules that govern transfers between related companies and reduce or eliminate the requirement that creditors prove wrongdoing in order to void such intercorporate transfers. ${ }^{34}$ By the same reasoning, the rules of automatic subordination and veil piercing would act as a prophylactic device to assure that corporate owners have not harmed the subsidiary at the expense of outside creditors. In practice, placing the burden of proving an elusive form of wrongdoing upon the creditors and the trustee necessarily discourages such claims in a great many cases where the costs of proof are too high. It is difficult to imagine any corporate law or bankruptcy policy that would deliberately perpetuate such a result.

5. The Pure Conglomerate. Professor Posner has expressed so much concern about the pure conglomerate that it seems appropriate to give it some special mention. In my view, the enterprise dangers noted above are equally present in the operation of the pure conglomerate, and I suspect that a careful study of the activities of its constituent units would show that such concerns function somewhat differently than would unaffiliated corporations in the same line of business. However, I do not think that it would undermine the enterprise rationale to develop a very limited exception for the pure conglomerate that could demonstrate an absence of extensive

3t See, e.g., United Towing Co. v. Phillips, 242 F.2d 627 (5th Cir. 1957); Palmer v. Stokely, 255 F. Supp. 674, 680-81 (W.D. Okla. 1966). 
reciprocal dealing either in goods or services or in financing or promotion, and could also show an independent management structure and an absence of direction from the owners of the enterprise. In the case of a newly acquired company, the factual showing would probably involve a comparison of pre-acquisition and post-acquisition levels of intercorporate activity, and in the case of developed subsidiaries, industry comparisons would be appropriate. I cannot think of any bankruptcy or veil piercing case that would come within such an exception, but for an occasional instance it may be worthwhile to make special provision.

\section{II}

In the final analysis, I believe that the real dispute between Professor Posner and myself concerns different perceptions about who the creditors in bankruptcy cases are. Professor Posner perceives the "consortium of banks" as the paradigm group of creditors and argues that, under the present system, they are well able to protect themselves. I hardly doubt the ability of the banks to protect themselves. But unlike Professor Posner, I find in the bankruptcy cases large numbers of involuntary, high-information-cost, and trade creditors who simply are not obtaining adequate protection under the present system. Moreover, since the threat of insolvency and bankruptcy may distort ordinary operating policies, it cannot always. be assumed that the corporate units will behave as charted on the economics drawing boards. In this circumstance, the enterprise approach serves a prophylactic function and curtails the high cost to creditors of attempting to prove the "true facts." To decide which perception of the identity of bankruptcy creditors is more accurate, I would suggest, respectfully, that one read the cases. ${ }^{35}$

${ }^{35}$ Cf. Coase, The Lighthouse in Economics, 17 J. Law \& Econ. 357, 374-75 (1974). 